\title{
Muscarine-Induced Increase in Frequency of Spontaneous EPSCs in Purkinje Cells in the Vestibulo-Cerebellum of the Rat
}

\author{
Yukihiro Takayasu, ${ }^{1,2,3}$ Masae Iino, ${ }^{1,3}$ Nobuhiko Furuya, ${ }^{2}$ and Seiji Ozawa ${ }^{1,3}$ \\ Departments of ${ }^{1}$ Physiology and ${ }^{2}$ Otolaryngology, Gunma University School of Medicine, Maebashi, Gunma, 371-8511, Japan, and ${ }^{3}$ Core Research for \\ Evolutional Science and Technology, Japan Science and Technology Corporation, Kawaguchi, Saitama 322-0012, Japan
}

\begin{abstract}
Cholinergic projections are relatively sparse in the cerebellum compared with other parts of the brain. However, some mossy fibers in the vestibulo-cerebellum are known to be cholinergic. To clarify the functional roles of cholinergic mossy fibers in the vestibulo-cerebellum, we investigated the effects of acetylcholine $(\mathrm{ACh})$ on the membrane electrical properties of both granule cells and Purkinje cells in slices of the cerebellar vermis of the rat using whole-cell patch-clamp techniques. The bath application of ACh induced a marked increase in the frequency of spontaneous EPSCs (sEPSCs) in Purkinje cells specifically in the vestibulo-cerebellum. This effect of ACh was mimicked by muscarine but not by nicotine. It was abolished by application of either tetrodotoxin or the antagonist of AMPA receptors, indicating that the ACh-induced enhancement of sEPSCs occurred indirectly via the activation of neurons sending glutamatergic projections to Purkinje cells. In $\sim 15 \%$ of granule cells tested in the vestibulo-cerebellum, muscarine elicited membrane depolarization accompanied by a decrease in membrane conductance and increased the neuronal excitability. The muscarine-induced depolarization of granule cells in the vestibulo-cerebellum was attributable to the inhibition of standing-outward $\mathrm{K}^{+}$currents $\left(I \mathrm{~K}_{\mathrm{SO}}\right)$ most likely via the activation of muscarinic $\mathrm{M}_{3}$ receptors. Taken together, these results indicate that ACh increases the firing frequency of granule cells by inhibiting $I \mathrm{~K}_{\mathrm{SO}}$, which in turn increases the frequency of sEPSCs in Purkinje cells in the rat vestibulo-cerebellum.
\end{abstract}

Key words: acetylcholine; vestibulo-cerebellum; Purkinje cell; granule cell; sEPSCs; muscarinic receptor; potassium current

\section{Introduction}

Cholinergic projections are relatively sparse in the cerebellum compared with other parts of the brain, such as the striatum, hippocampus, and basal forebrain (Schäfer et al., 1998). However, previous studies using ligand-binding autoradiography (Spencer et al., 1986; Neustadt et al., 1988; Araujo et al., 1991), in situ hybridization (Wada et al., 1989; Vilaró et al., 1992), and immunocytochemistry (Swanson et al., 1987; Levey et al., 1991) revealed the presence of both nicotinic and muscarinic receptors in specific regions of the cerebellum.

The vestibular system has a close relationship with the cerebellum. The labyrinth sends primary afferents ipsilaterally to the nodulus and uvula in the cerebellum. Neurons of the superior, medial, lateral, and descending vestibular nuclei send their axons bilaterally to the nodulus, uvula, lingual, flocculus, and ventral paraflocculus. These cerebellar regions are referred to as the vestibulo-cerebellum (Altman and Bayer, 1997). Although most mossy fiber projections into the cerebellum are glutamatergic, some mossy fiber terminals of secondary vestibular projections into the vestibulo-cerebellum contain choline acetyltransferase

Received Feb. 3, 2003; revised May 6, 2003; accepted May 13, 2003

We thank Drs. Keisuke Tsuzuki, Yasuhiko Saito, and Wataru Kakegawa for helpful suggestions and discussions on this manuscript.

Correspondence should be addressed to Dr. Seiji Ozawa, Department of Physiology, Gunma University School of Medicine, 3-39-22 Showa-machi, Maebashi, Gunma 371-8511, Japan. E-mail: ozawas@med.gunma-u.ac.jp.

Copyright $\odot 2003$ Society for Neuroscience $\quad 0270-6474 / 03 / 236200-09 \$ 15.00 / 0$ and cholinesterase abundantly, implying the participation of acetylcholine (ACh) in synaptic transmission between mossy fiber terminals and cerebellar neurons (Ojima et al., 1989; Barmack et al., 1992). This notion is supported by behavioral studies showing that the injection of cholinergic agonists into the vestibulocerebellum influences the gains of vestibulo-spinal, vestibuloocular, and optokinetic reflexes (Tan and Collewijn, 1991; Tan et al., 1993). However, systematic studies on the effects of ACh on cerebellar neurons have not been performed. It was reported that the iontophoretic application of ACh increased the spontaneous firing rates of Purkinje and granule cells in the cerebellum (McCance and Phillis, 1964; Crawford et al., 1966). Several studies suggested that ACh exerted a direct action on Purkinje cells via muscarinic receptors (Crawford et al., 1966; Crepel and Dhanjal, 1982; Andre et al., 1993; Tan et al., 1993). However, anatomical studies showed that Purkinje cells in most species had no muscarinic receptors (Vilaró et al., 1992; Jaarsma et al., 1997), supporting the possibility that ACh elicited the excitation of Purkinje cells indirectly as a consequence of its action on neighboring granule cells (McCance and Phillis, 1964, 1968). Thus, the mechanism underlying the excitatory effects of ACh on cerebellar neurons is, for the most part, unknown (Jaarsma et al., 1997).

To clarify the functional roles of cholinergic mossy fibers in the vestibulo-cerebellum, we investigated the effects of ACh on the membrane electrical properties of both Purkinje cells and granule cells in the cerebellum using whole-cell patch-clamp 
techniques. We found that $\mathrm{ACh}$ directly induced depolarization of granule cells through their muscarinic receptors, resulting in a marked increase in the frequency of spontaneous EPSCs (sEPSCs) in Purkinje cells specifically in the vestibulo-cerebellum. We also found that the ACh-induced depolarization of granule cells was attributable to the inhibition of standing-outward $\mathrm{K}^{+}$currents $\left(I \mathrm{~K}_{\mathrm{SO}}\right)$ most likely via the activation of muscarinic $\mathrm{M}_{3}$ receptors.

\section{Materials and Methods}

Slice preparation. Experiments were performed in slices of the cerebellar vermis of postnatal 19- to 22-d-old Wistar rats. Procedures for preparation and maintenance of slices were similar to those described previously (Iino et al., 2001). Animals of either sex were deeply anesthetized with isoflurane and were killed by decapitation. The cerebellar vermis was rapidly removed, glued to the stage of a vibratome (DTK-1000; DosakaEM, Kyoto, Japan), and immersed in ice-cold $\left(0-4^{\circ} \mathrm{C}\right)$, oxygenated $(95 \%$ $\mathrm{O}_{2}$ and $5 \% \mathrm{CO}_{2}$ ) external solution. Parasagittal slices $200 \mu \mathrm{m}$ in thickness were incubated in external solution at $30^{\circ} \mathrm{C}$ for $1 \mathrm{hr}$ and subsequently maintained at room temperature for up to $8 \mathrm{hr}$. For recording, the slice was transferred to a $2.5 \mathrm{ml}$ recording chamber mounted on the stage of an upright microscope (Axioskop; Zeiss, Oberkochen, Germany) and perfused at a rate of $2 \mathrm{ml} / \mathrm{min}$ with external solution maintained at $30^{\circ} \mathrm{C}$ with a solution in-line heater (SH-27A; Warner Instruments, Hamden, CT). All experiments were performed according to the guidelines approved by the Animal Care and Experimentation Committee of Gunma University.

Whole-cell patch-clamp recordings. Slices were visualized using a $60 \times$ water-immersion objective illuminated with near-infrared light. The image was collected with a CCD camera (C2741; Hamamastu Photonics, Hamamastu, Japan) with contrast enhancement and displayed on a video monitor. Whole-cell patch-clamp recordings (Edwards et al., 1989) were taken from visualized Purkinje and granule cells. Patch pipettes were pulled from borosilicate glass capillaries (GC150F-15; Harvard Apparatus, Holliston, MA) using a Flaming-Brown-type horizontal puller (PC97; Sutter Instruments, Novato, CA). When filled with the intracellular solutions, the resistances of the pipettes were 3-5 M $\Omega$ for recording of Purkinje cells and 6-8 M $\Omega$ for recording of granule cells. An EPC-8 patch-clamp amplifier (HEKA, Darmstadt, Germany) was used for recording, and a pCLAMP system (version 7; Axon Instruments, Foster City, CA) was used for data acquisition and analysis. A current transient elicited by a $10 \mathrm{mV}$ hyperpolarizing pulse from the holding potential of $-70 \mathrm{mV}$ in the whole-cell voltage-clamp mode was given to estimate the series resistance, input resistance, and capacitance. The series resistance during recording from Purkinje cells was $13.0 \pm 1.8 \mathrm{M} \Omega$, and the input resistance was $190 \pm 65 \mathrm{M} \Omega$. Series resistance compensation was not used. For recording from granule cells, the perforated patch-clamp technique (Rae et al., 1991) was used to prevent cytoplasmic washout. The tip of the electrode was filled with control solution and back-filled with the same solution containing $240 \mu \mathrm{g} / \mathrm{ml}$ amphotericin B. The series resistance using this procedure generally did not exceed $50 \mathrm{M} \Omega(38.0 \pm 9.2$ $\mathrm{M} \Omega ; n=30)$. Current and voltage signals were filtered at $3 \mathrm{kHz}$ and digitized at $5 \mathrm{kHz}$ for voltage-clamp recording or $20 \mathrm{kHz}$ for currentclamp recording. Because the liquid junction potential between the external and internal solutions was estimated to be $-10 \mathrm{mV}$, the actual membrane potential was corrected by this value.

Data analysis. sEPSCs and miniature EPSCs (mEPSCs) were counted and analyzed using the MiniAnalysis program (Synaptosoft). Spontaneous events at the holding potential of $-70 \mathrm{mV}$ were initially detected automatically using our tentative criteria, which were set to an amplitude threshold of $15 \mathrm{pA}$ and an area threshold of $60 \mathrm{fC}$ for sEPSCs and $10 \mathrm{pA}$ and $7 \mathrm{fC}$ for mEPSCs and then visually accepted or rejected on the basis of the rise and decay times. A charge transfer of sEPSC was calculated by summing up the areas of detected events every $10 \mathrm{sec}$. Origin (Microcal Software, Northampton, MA) was also used for data analysis. Data are given as mean \pm SEM. For statistical analysis, the Wilcoxon test, Kolmogorov-Smirnov test, or Mann-Whitney $U$ test was performed.

Solutions. The control external solution contained (in mM): $125 \mathrm{NaCl}$,
$2.5 \mathrm{KCl}, 2 \mathrm{CaCl}_{2}, 1 \mathrm{MgCl}_{2}, 1.25 \mathrm{NaH}_{2} \mathrm{PO}_{4}, 26 \mathrm{NaHCO}_{3}$, and 10 glucose. The external solution with high $\mathrm{K}^{+}$concentration contained (in $\mathrm{mM}$ ): $102.5 \mathrm{NaCl}, 25 \mathrm{KCl}, 2 \mathrm{CaCl}_{2}, 1 \mathrm{MgCl}_{2}, 1.25 \mathrm{NaH}_{2} \mathrm{PO}_{4}, 26 \mathrm{NaHCO}_{3}$, and 10 glucose, $\mathrm{pH} 7.4$ at $32^{\circ} \mathrm{C}$ when bubbled with $95 \% \mathrm{O}_{2}$ and $5 \% \mathrm{CO}_{2}$. In all experiments, $100 \mu \mathrm{M}$ picrotoxin (Wako Chemicals, Osaka, Japan) was continuously added to the external solution to block $\mathrm{GABA}_{\mathrm{A}}$ receptormediated currents. For voltage-clamp recordings of granule cells, $0.3 \mu \mathrm{M}$ tetrodotoxin (TTX) was also added to block voltage-dependent $\mathrm{Na}^{+}$ currents. The internal solution used for conventional whole-cell recordings of Purkinje cells contained (in mM): 150 Cs-gluconate, $8 \mathrm{NaCl}, 2$ Mg-ATP, 10 HEPES, 0.1 spermine, and $5 \mathrm{~N}$-ethyl bromide quaternary salt (QX-314) (Sigma, St. Louis, MO). The $\mathrm{pH}$ was adjusted to 7.2 with gluconic acid. QX-314 was added to the internal solution to avoid $\mathrm{Na}^{+}$ current-mediated escape from the voltage clamp. The internal solution for perforated patch recording of granule cells contained (in $\mathrm{mM}$ ): 125 K-gluconate, $5 \mathrm{MgCl}_{2}, 10 \mathrm{HEPES}$, and $0.2 \mathrm{EGTA}$. The $\mathrm{pH}$ was adjusted to 7.2 with gluconic acid. As a permeabilizing agent, $240 \mu \mathrm{g} / \mathrm{ml}$ amphotericin B (Sigma) was added to the internal solution.

Drugs. Drugs used in this study were ACh, (+)-muscarine chloride, (-)-nicotine, mecamylamine, atropine, 4-diphenylacetoxy- $\mathrm{N}$ methylpiperidine methiodide (4-DAMP), methoctramine tetrahydrochloride, (+)-himbacine, $p$-fluoro-hexahydrosiladifenidol hydrochloride ( $p$-F-HHSiD) (Sigma), 6-cyano-7-nitroquinoxaline-2,3-dione (CNQX) (Tocris Cookson, Bristol, UK), and TTX (Wako Chemicals). Drugs were dissolved in distilled water or DMSO at concentrations of 1-10 mM and stored. The final concentrations of the drugs in Results were obtained by diluting the stock solutions with the recording external solution. The final DMSO concentration was lower than $0.1 \%$. All drugs were bath-applied via gravity feed at a rate of $4-5 \mathrm{ml} / \mathrm{min}$, resulting in solution exchange within $30 \mathrm{sec}$.

\section{Results}

\section{Effects of ACh on spontaneous EPSCs in Purkinje cells in the vestibulo-cerebellum}

sEPSCs were recorded in Purkinje cells voltage-clamped at -70 $\mathrm{mV}$ in the cerebellar vermal lobule $\mathrm{X}$ (nodules) in the vestibulocerebellum. Bath application of ACh $(100 \mu \mathrm{M})$ markedly increased the frequency of sEPSCs (Fig. 1A). These sEPSCs were completely and reversibly abolished by the bath application of 10 $\mu \mathrm{M}$ CNQX (Fig. 1B). Furthermore, these inward currents reversed at $\sim 0 \mathrm{mV}$ (data not shown). These results suggested that the sEPSCs were generated by the activation of AMPA-type glutamate receptors. The ACh-induced increase in the frequency of sEPSCs was abolished by adding $1 \mu \mathrm{M}$ TTX (Fig. 1C), indicating that the effect of ACh was mediated by an action potentialdependent release of excitatory transmitters from presynaptic neurons.

To determine whether nicotinic or muscarinic receptors contributed to the ACh-induced event, we examined the effects of additional applications of mecamylamine $(10 \mu \mathrm{M})$, a nicotine receptor antagonist, and atropine $(1 \mu \mathrm{M})$. The ACh-induced event was unaffected by mecamylamine but inhibited by atropine (Fig. 1D). In addition, the effect of ACh was mimicked by bath application of $30 \mu \mathrm{M}$ muscarine but not by $30 \mu \mathrm{M}$ nicotine (Fig. $1 E)$. These results indicated that the effect of ACh was attributable to the indirect action on muscarinic receptors of presynaptic neurons. For the rest of this study, we used muscarine as the cholinergic receptor agonist.

We examined the effects of muscarine on the frequency, amplitude, and charge transfer of sEPSCs in Purkinje cells in the vestibulo-cerebellum. Figure 2, $A$ and $B$, shows typical current traces recorded in a Purkinje cell and the time courses of changes in the frequency (Fig. $2 B, a$ ), amplitude (Fig. $2 B, b$ ), and charge transfer (Fig. 2B, $c$ ) of sEPSCs every $10 \mathrm{sec}$ before and during bath application of muscarine. Muscarine $(10 \mu \mathrm{M})$ increased the frequency, mean amplitude, and charge transfer of sEPSCs in $10 \mathrm{sec}$ 


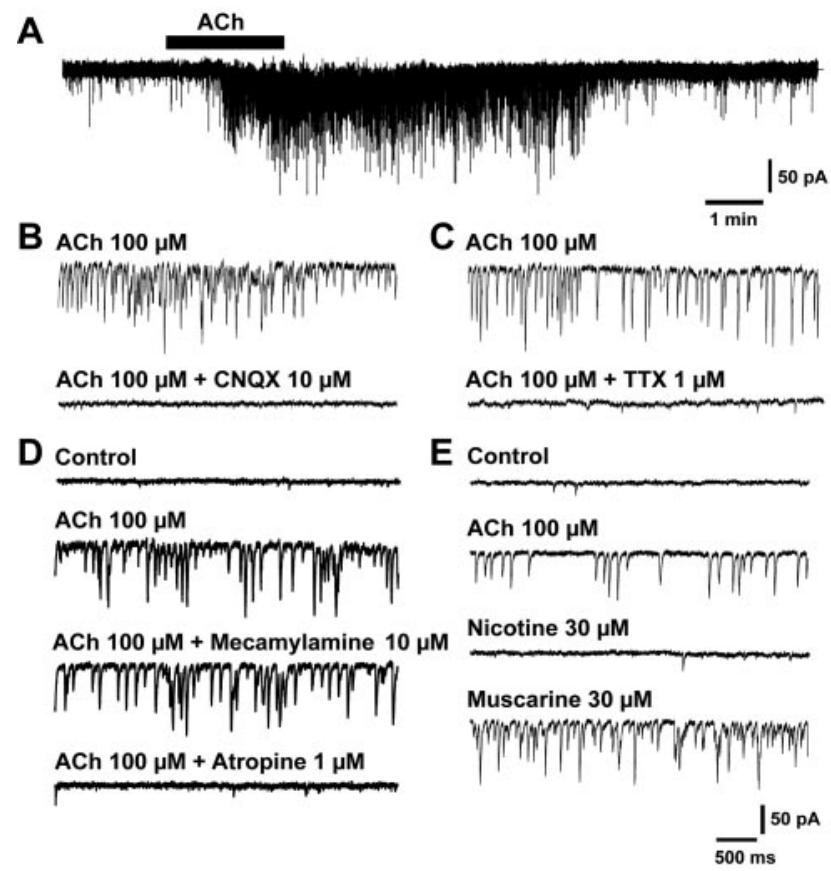

Figure 1. Effects of ACh on sEPSCs in Purkinje cells in lobule X. A, Increase in the frequency of sEPSCs in Purkinje cells induced by ACh (100 $\mu \mathrm{m}, 90 \mathrm{sec}$ ). B, C, Suppression of effects of ACh by either CNQX (10 $\mu \mathrm{M})$ or TTX (1 $\mu \mathrm{M})$. D, Effects of mecamylamine $(10 \mu \mathrm{M})$ and atropine $(1 \mu \mathrm{M})$ on ACh-induced enhancement of $S E P S C S$. E, Effects of nicotine $(30 \mu \mathrm{m})$ and muscarine $(30 \mu \mathrm{M})$. The membrane potential was held at $-70 \mathrm{mV}$.

to 18.4-, 2.3-, and 46.1-fold of the control, respectively ( $n=8$; $p<0.01$ in all three parameters) (Fig. $2 C$ ). In contrast, the bath application of $10 \mu \mathrm{M}$ muscarine caused no change in both frequency and amplitude of TTX-insensitive mEPSCs (Fig. 2D). Because muscarine invariably increased both frequency and amplitude of the sEPSC, we estimated the degree of the muscarineinduced effects using sEPSC charge transfer in this study.

\section{Dose dependence of muscarine effect}

The muscarine-induced increase in sEPSC charge transfer was reproducible even after repeated applications of muscarine. Figure 3, $A$ and $B$, shows typical current traces and time courses of sEPSC charge transfer every $10 \mathrm{sec}$ during repeated applications of various concentrations of muscarine to a Purkinje cell. To obtain a dose-response relationship for the muscarine effect on sEPSCs, we bath-applied various concentrations of muscarine from $1 \mathrm{~nm}$ to $30 \mu \mathrm{M}$ and measured the increase in sEPSC charge transfer every $10 \mathrm{sec}$. In Figure $3 C$, we plotted the peak value of the increase in charge transfer in $10 \mathrm{sec}$ at various concentrations of muscarine normalized to that at $1 \mu \mathrm{M}$ muscarine against muscarine concentration. The response to muscarine was negligible at $<1 \mathrm{~nm}$ and almost saturated at $30 \mu \mathrm{m}$. The maximum charge transfer in $10 \mathrm{sec}$ was $205.0 \pm 111 \mathrm{pC}(n=5)$, and the best nonlinear least squares fit to these data predicted a half-maximal response at $0.289 \mu \mathrm{M}$ and a Hill coefficient of 0.739 .

\section{Difference in muscarine effects among Purkinje cells in different cerebellar lobules}

The presence of muscarinic receptors in the cerebellum has been demonstrated by previous studies (Neustadt et al., 1988; Jaarsma et al., 1997). In respect to their distribution, in situ hybridization study has shown that muscarinic receptors are found to be most dense in the granule cell layer of lobules IX (uvula) and X in the vestibulo-cerebellum (Vilaró et al., 1992). To determine whether the effect of muscarine differs among Purkinje cells in different cerebellar lobules, we compared the sEPSC charge transfer at 1 $\mu \mathrm{M}$ muscarine in the vestibulo-cerebellar lobules (IX and X) with that in other lobules (IV-VI).

Figure $4 A$ shows histograms giving the distribution of sEPSC charge transfer in $10 \mathrm{sec}$ in the control solution and in the presence of $1 \mu \mathrm{M}$ muscarine in 89 Purkinje cells in lobules IX and X and 23 cells in lobules IV-VI. In lobules IX and X, the sEPSC charge transfer was $<10 \mathrm{pC} / 10 \mathrm{sec}$, and its mean value was $3.8 \pm$ $0.3 \mathrm{pC} / 10 \mathrm{sec}$ in the control solution $(n=89)$. In the presence of $1 \mu \mathrm{M}$ muscarine, it increased markedly, and the peak value was widely distributed between 14.9 and $392.5 \mathrm{pC} / 10 \mathrm{sec}$, with a mean of $141.7 \pm 9.6 \mathrm{pC} / 10 \mathrm{sec}(n=89 ; p<0.0001)$ (Fig. $4 A, a)$. In lobules IV-VI, the corresponding value in control solution was slightly smaller than that in lobules IX and X $(1.1 \pm 0.5 \mathrm{pC} / 10 \mathrm{sec}$; $n=23 ; p=0.027)$. The application of $1 \mu \mathrm{M}$ muscarine caused no significant increase in this value in 20 cells $(p=0.191)$, whereas it caused a substantial increase in the remaining three cells, in which the peak sEPSC charge transfer in $10 \mathrm{sec}$ ranged between 44.4 and $92.6 \mathrm{pC} / 10 \mathrm{sec}$ (Fig. $4 A, b$ ). As a whole, therefore, the sEPSC charge transfer in the presence of $1 \mu \mathrm{M}$ muscarine was much greater in lobules IX and $\mathrm{X}$ than that in lobules IV-VI $(141.7 \pm 9.6 \mathrm{pC} / 10 \mathrm{sec} ; n=89 ; \mathrm{vs} 10.8 \pm 2.8 \mathrm{pC} / 10 \mathrm{sec} ; n=23$, respectively; $p<0.0001$ ) (Fig. $4 B$ ). These results indicated that the muscarine-induced increase in sEPSC charge transfer in Purkinje cells occurred much more prominently in the vestibulo-cerebellum.

Suppression of the effect of muscarine by muscarinic $\mathrm{M}_{2}$ and $\mathrm{M}_{3}$ receptor antagonists

It has been reported that the majority of muscarinic receptors in the cerebellum are of the $M_{2}$ type, and very few $M_{3}$-type receptors are detected (Tice et al., 1996; Jaarsma et al., 1997). On the other hand, it has been shown that the cerebellar granule cells in culture express both $M_{2}$ and $M_{3}$ receptors where $M_{3}$ receptors are predominant (Fukamauchi et al., 1991, 1993). To clarify the subtype of the muscarinic receptors underlying the enhancement of sEPSCs, we used five muscarinic receptor antagonists: atropine, methoctramine, himbacine, 4-DAMP, and p-F-HHSiD. It has been reported that atropine is subtype nonselective; methoctramine and himbacine are $\mathrm{M}_{2}$-selective; and 4-DAMP and $p$-F$\mathrm{HHSiD}$ are $\mathrm{M}_{3}$-selective antagonists (Hulme et al., 1990).

To obtain concentration-response relationships of the suppressive effects of the antagonists, $1 \mu \mathrm{M}$ muscarine was repeatedly bath-applied first in the absence and then in the presence of various concentrations of the antagonists in the same neuron. Figure 5, $A, a$, and $B, a$, exemplifies typical traces of sEPSCs in the solution containing $1 \mu \mathrm{M}$ muscarine without and with various concentrations of the nonselective antagonist atropine or the $\mathrm{M}_{3}$ selective antagonist 4-DAMP. We calculated the relative increase in charge transfer, that is, the peak increase in charge transfer in $10 \mathrm{sec}$ in the presence of various concentrations of the antagonists divided by that obtained without them. In the graphs, we plotted these relative values against the concentrations of the antagonists (Fig. $5 A, b, B, b$ ). The best nonlinear least squares fit to the concentration-response curves predicted $\mathrm{IC}_{50}$ values of 3.34 and 2.50 $\mathrm{nM}$ for atropine and 4-DAMP, respectively. The $\mathrm{IC}_{50}$ values for the other antagonists were $2.79 \mu \mathrm{M}$ (methoctramine), $423 \mathrm{nM}$ (himbacine), and $55.8 \mathrm{~nm}$ ( $p$-F-HHSiD).

The receptor binding studies for these antagonists of muscarinic receptors revealed that $K_{\mathrm{i}}$ values of methoctramine and himbacine for muscarinic $\mathrm{M}_{2}$ receptors were $\sim 15$ - to $\sim 10$-fold 
A Control

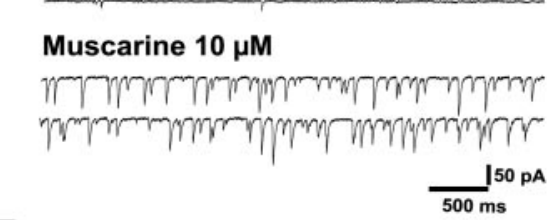

D
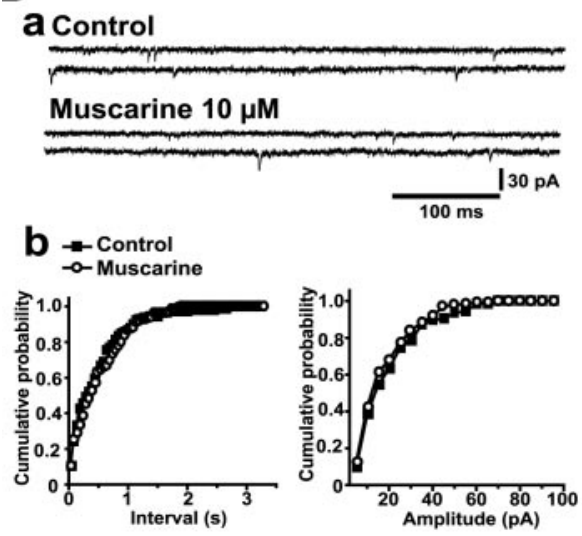

B a

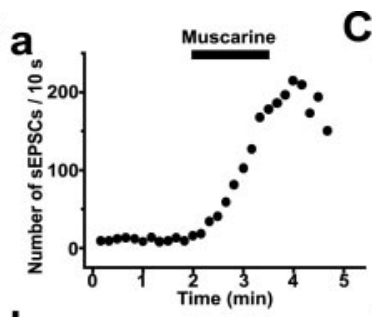

b

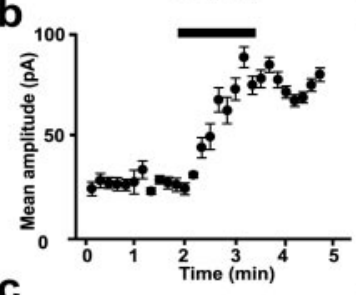

C

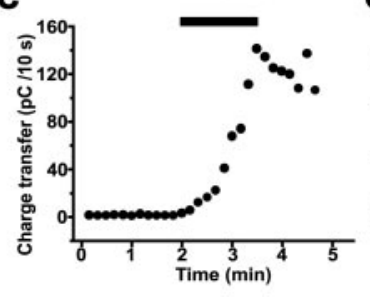

Figure 2. Effects of muscarine on the frequency, amplitude, and charge transfer of sEPSCS. A, Typical traces of sEPSCS 10 sec before and during the bath application of muscarine $(10 \mu \mathrm{M})$. $B$, Time course of effects of muscarine on the frequency, mean amplitude, and charge transfer of sEPSCs in the experiment shown in $A$. $a$, Time course of change in sEPSC frequency. The number of events every 10 sec was summed and plotted. $b$, Time course of change in mean amplitude of $s E P S C s$. Each plot represents the mean \pm SEM of sEPSC amplitudes every 10 sec. c, Time course of charge transfer of sEPSCs. The area of events every 10 sec was summed and plotted as the charge transfer of sEPSC in 10 sec. Horizontal bars indicate the period during muscarine application ( 90 sec). C, Means \pm SEM of sEPSC frequency ( $a$ ), amplitude $(b)$, and charge transfer $(c)$ before and during application of muscarine $(n=8)$. All columns were normalized to the respective control (dotted lines; ${ }^{*} p<0.01$, Wilcoxon test). Cont, Control; Mus, muscarine. $D, a$, Typical traces of mEPSCs recorded in the presence of TTX $(1 \mu \mathrm{M})$ from the same neuron shown in $A$ before and during application of muscarine $(10 \mu \mathrm{m})$. b. Cumulative probabilities of interval and amplitude of mEPSCs before $(n=135)$ and during ( $n=137$ ) application of muscarine ( $p=0.517$, interval; $p=0.625$, amplitude; Kolmogorov-Smirnov test).

higher than that of atropine, and those of 4-DAMP and p-FHHSiD for muscarinic $\mathrm{M}_{3}$ receptors were nearly identical to and $\sim 40$-fold higher than that of atropine, respectively (Dörje et al., 1991; Dong et al., 1995; Caulfield and Birdsall, 1998). In this experiment, the $\mathrm{IC}_{50}$ value of 4-DAMP was in a range similar to that of atropine, and that of $p$-F-HHSiD was $\sim 20$-fold higher than that of atropine. On the other hand, the $\mathrm{IC}_{50}$ values of methoctramine and himbacine were $\sim 840$ - and $\sim 130$-fold higher than that of atropine. These results strongly suggested that muscarinic $\mathrm{M}_{3}$ receptors mainly mediated the muscarine-induced enhancement of sEPSCs in Purkinje cells in the vestibulo-cerebellum (also see Discussion).

Effects of muscarine on excitability of cerebellar granule cells The results described above strongly suggested that the muscarine-induced enhancement of sEPSCs in Purkinje cells was attributable to the increase in the excitability of granule cells that send excitatory signals to Purkinje cells via parallel fibers. Therefore, we decided to examine whether muscarine affects the excitability of granule cells in lobule $\mathrm{X}$ using a perforated patch-clamp technique.

The granule cells in the control condition were held at approximately $-70 \mathrm{mV}$ with current injection, and depolarizing current pulses were injected at $0.1 \mathrm{~Hz}$ to assess the membrane conductance. Bath application of $5 \mu \mathrm{M}$ muscarine for $90 \mathrm{sec}$ caused membrane depolarization that lasted for several minutes in 13 of 84 cells tested (15.5\%) (Fig. 6A). The peak amplitude of this a

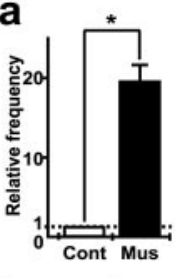

b

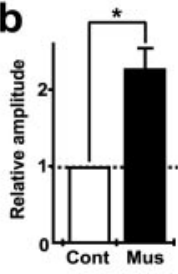

C

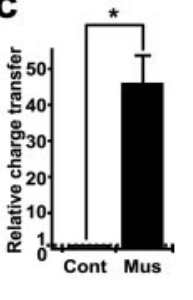

depolarization was $8.3 \pm 3.0 \mathrm{mV}(n=13)$. Action potentials were occasionally elicited by the injection of depolarizing current pulses during the muscarine-induced depolarization (Fig. 6A, b). We also estimated the muscarine-induced changes in the membrane conductance by passing hyperpolarizing current pulses in granule cells that were sensitive to muscarine. For this experiment, the membrane potential was held at $-60 \mathrm{mV}$ before and during application of $5 \mu \mathrm{M}$ muscarine by adjusting the intensity of injection current by hand. Muscarine at $5 \mu \mathrm{M}$ reduced the membrane conductance to $74 \pm 7 \%$ of the control $(n=4)$ (Fig. $6 B)$. This suggested that the muscarine-induced depolarization was attributable to a decrease in the $\mathrm{K}^{+}$conductance.

In contrast, no muscarine-induced depolarization and reduction of membrane conductance were observed in all granule cells tested in lobules IV-VI $(n=39)$. These results obtained in granule cells were consistent with those in Purkinje cells in the lobular localization of muscarinic effects.

\section{Inhibition of leak $\mathrm{K}^{+}$current by muscarine in granule cells}

Previous studies in a variety of preparations (Madison et al., 1987; Jones and Baughman, 1992), including rat cerebellar granule cells in primary culture (Watkins and Mathie, 1996), reported that muscarinic receptors elicited a membrane depolarization by inhibiting a voltage-independent leak $\mathrm{K}^{+}$current, designated as standing-outward $\mathrm{K}^{+}$current $\left(I \mathrm{~K}_{\mathrm{SO}}\right)$. To examine whether muscarine-sensitive $I \mathrm{~K}_{\mathrm{SO}}$ is detected in granule cells in the rat vestibulo-cerebellum as reported previously in mouse granule cells in slices (Millar et al., 2000; Brickley et al., 2001), we performed voltage-clamp analyses in granule cells in lobule $\mathrm{X}$ using a perforated patch-clamp technique. Figure 7 shows a typical example of such analyses. Here, the membrane potential of a granule cell was held at $-30 \mathrm{mV}$ in the presence of TTX $(1 \mu \mathrm{M})$ and then stepped down to $-80 \mathrm{mV}$ for $0.8 \mathrm{sec}$ at $0.1 \mathrm{~Hz}$. The noninactivating outward current at $-30 \mathrm{mV}$ that was reversibly inhibited by $5 \mu \mathrm{M}$ muscarine was detected in 12 of 91 cells tested (13.2\%) (Fig. 7A, $a, b$ ). The mean amplitude of the muscarinesensitive current at $-30 \mathrm{mV}$ obtained by subtraction was $38.6 \pm$ $13.0 \mathrm{pA}(n=12)$.

To obtain the current-voltage relationship and the reversal potential of muscarine-sensitive current, we used the ramp voltage protocol in which the membrane potential was ramped from the holding potential of -30 to $-100 \mathrm{mV}$ at a rate of $-0.07 \mathrm{mV} /$ msec. Figure $7 B$ shows typical current traces obtained with this protocol in the presence and absence of $5 \mu \mathrm{M}$ muscarine. The muscarine-sensitive current was obtained by subtracting the current in the presence of muscarine from that in its absence. In the control external solution containing $2.5 \mathrm{mM} \mathrm{K}^{+}$, in which $E_{\mathrm{K}}$ was calculated to be $-102 \mathrm{mV}$, the muscarine-sensitive current was outwardly rectifying and not measurable at potentials more negative than $-90 \mathrm{mV}(n=6)$. In high- $\mathrm{K}^{+}$solution containing $25 \mathrm{mM} \mathrm{K} \mathrm{K}^{+}$ 


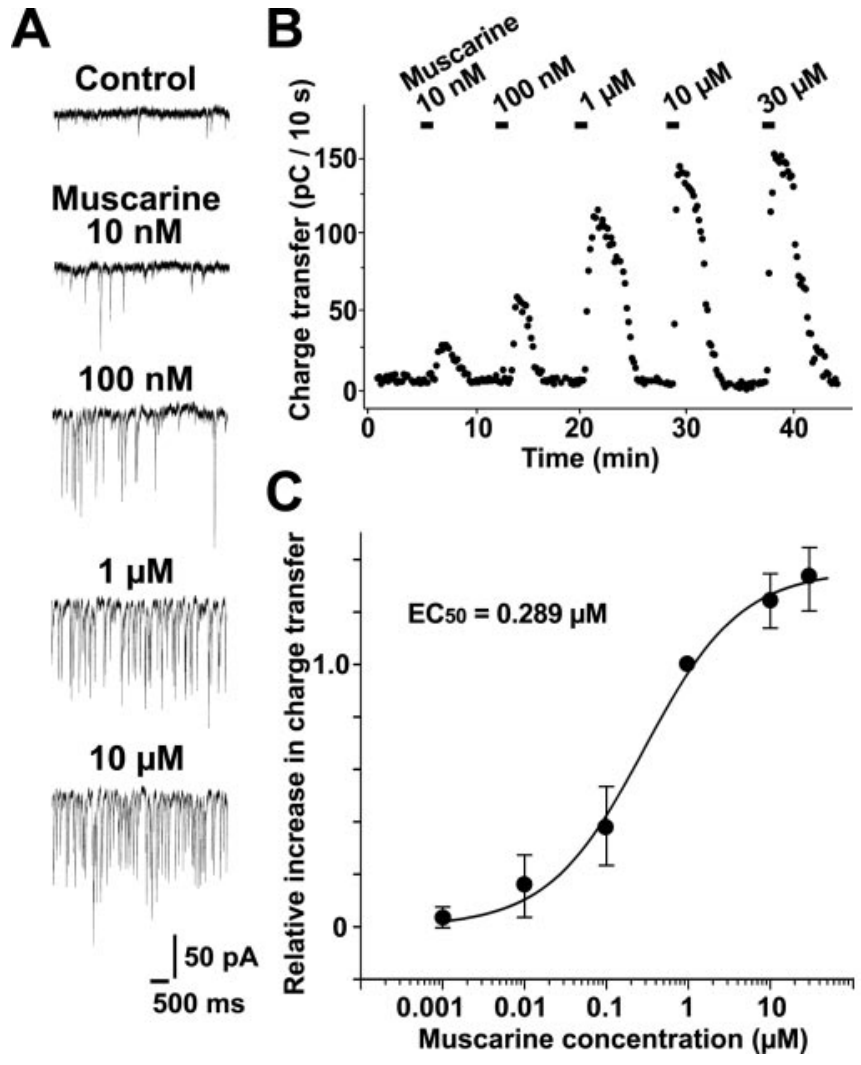

Figure 3. Dose dependence of effects of muscarine. A, Typical traces of sEPSCS before and during application of different concentrations of muscarine (10 and $100 \mathrm{~nm}, 1$ and $10 \mu \mathrm{M}$ ). $B$, Time course of the increase in sEPSC charge transfer induced by the successive applications of different concentrations of muscarine. The SEPSC charge transfer every $10 \mathrm{sec}$ was plotted against time. The current traces in $A$ and the plots in $B$ were obtained from the same cell. $C$, Dose-response relationship of the effect of muscarine. The peak value of the increase in sEPSC charge transfer induced by each muscarine concentration as shown in $B$ relative to that induced by $1 \mu \mathrm{m}$ muscarine is plotted against the concentration of muscarine. Each circle and bar represent the mean \pm SEM of the relative peak value obtained from 5-13 cells. The line through the circles is the best nonlinear least squares fit to the equation $S=S_{\max } /\left[1+\left(\mathrm{EC}_{50} / C^{\mathrm{n}}\right]\right.$, where $S$ is the relative peak value; $S_{\max }$ is the maximal peak value; and $($ is the concentration of muscarine. The best fit yields an $\mathrm{EC}_{50}$ of $0.289 \mu \mathrm{m}$ and a Hill coefficient of 0.739 .

prepared by isomolar replacement of $\mathrm{NaCl}$ with $\mathrm{KCl}$, the muscarinesensitive current reversed at $-44.5 \pm 2.6 \mathrm{mV}(n=4)$ (Fig. 7C). This reversal potential was close to $E_{\mathrm{K}}$ calculated to be $-42.0 \mathrm{mV}$, indicating that the muscarine-sensitive current detected here was a selective $\mathrm{K}^{+}$current. Thus, the muscarine-sensitive outward current recorded here was identical to $I \mathrm{~K}_{\mathrm{SO}}$ reported previously as noninactivating $\mathrm{K}^{+}$current (Watkins and Mathie, 1996).

Inhibition of the leak $\mathrm{K}^{+}$current by muscarine is abolished by muscarinic $M_{3}$ receptor antagonist

We suggested that muscarine-induced enhancement of sEPSCs in Purkinje cells was attributable to the activation of muscarinic $\mathrm{M}_{3}$ receptors (Fig. 5). If this is the case, it would be expected that the leak $\mathrm{K}^{+}$current is inhibited by activation of muscarinic $\mathrm{M}_{3}$ receptors. Therefore, we examined the effects of methoctramine $\left(\mathrm{M}_{2}\right.$ antagonist $)$ and 4-DAMP $\left(\mathrm{M}_{3}\right.$ antagonist $)$ on muscarine sensitivity of leak $\mathrm{K}^{+}$current in granule cells (Fig. 8). In the presence of $1 \mu \mathrm{M}$ methoctramine, the amplitude of muscarinesensitive current at $-30 \mathrm{mV}$ was $35.0 \pm 5.9 \mathrm{pA}(n=4)$, which was similar to $35.8 \pm 7.2 \mathrm{pA}(n=4)$ in the control condition. In contrast, muscarine produced no detectable inhibition of leak $\mathrm{K}^{+}$current in the presence of $30 \mathrm{nM} 4$-DAMP $(n=4)$. This
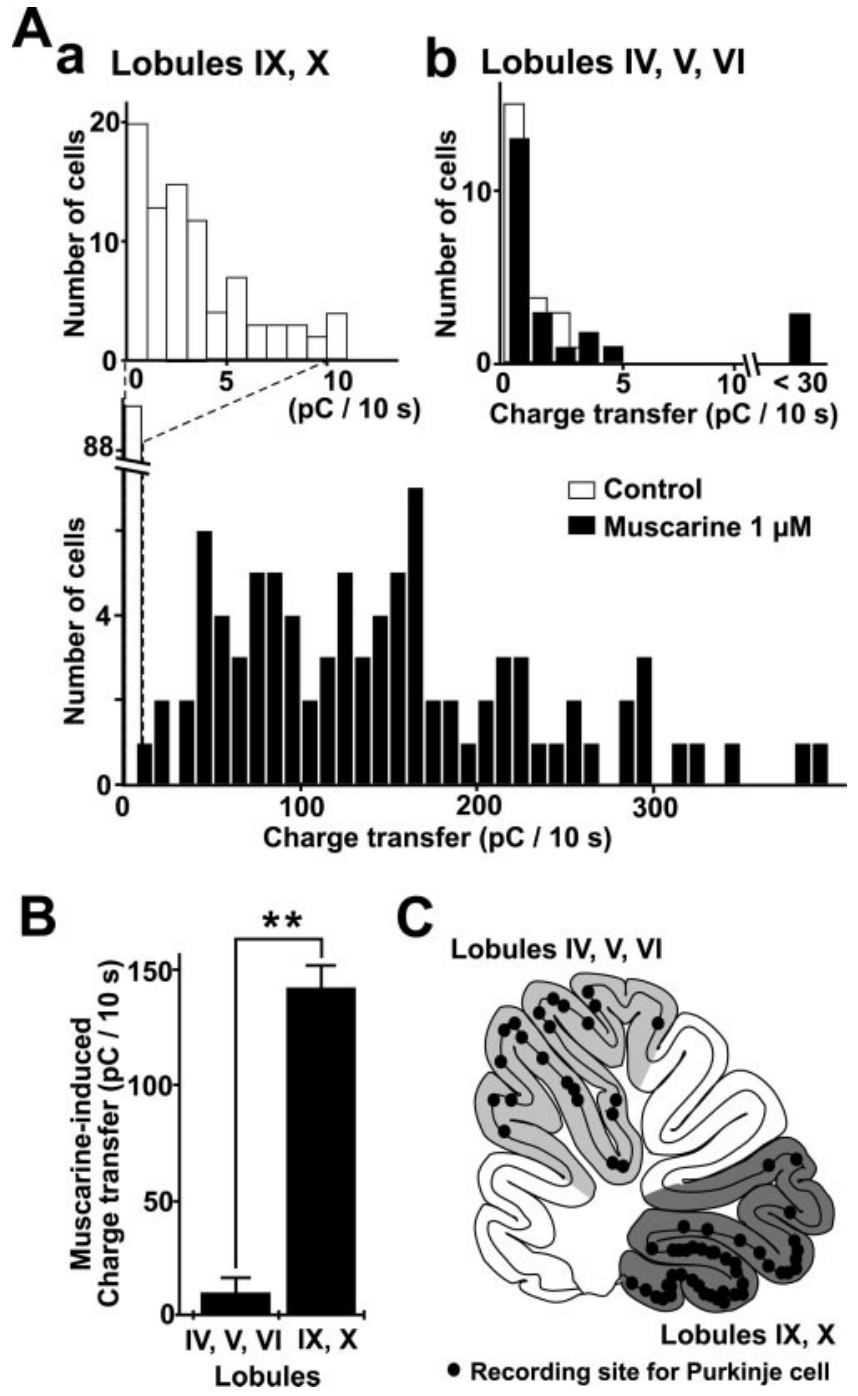

Figure 4. Difference in the effects of muscarine on sEPSC enhancement among Purkinje cells in the different lobules. The sEPSC charge transfer every 10 sec before and during the application of $1 \mu \mathrm{m}$ muscarine was measured in Purkinje cells in the vestibulo-cerebellar lobules (IX,X) and other lobules (IV-VI). A, a, Distributions of sEPSC charge transfers in $10 \mathrm{sec}$ in the control condition (the average of the value for $1 \mathrm{~min}$; top histogram, open bars) and during the application of $1 \mu \mathrm{m}$ muscarine (bottom histogram, filled bars) in 89 Purkinje cells in the vestibulocerebellar lobules (IX,X). The peak value was taken for the sEPSC charge transfer in 10 sec during the application of muscarine. $A, b$, Distribution of sEPSC charge transfers in 10 sec in the control condition (open bars) and during the application of $1 \mu \mathrm{m}$ muscarine (filled bars) in 23 Purkinje cells in lobules IV-VI. $B$, Means \pm SEM of sEPSC charge transfers in the presence of $1 \mu \mathrm{m}$ muscarine in Purkinje cells in lobules IV-VI ( $n=23$; left column), and IX and X ( $n=89$; right column). ${ }^{* *} p<0.0001$, Mann-Whitney $U$ test. $C$, Recording sites of Purkinje cells on the schematic view of parasagittal slices of the vermis.

strongly suggested that the activation of muscarinic $\mathrm{M}_{3}$ receptors was responsible for the inhibition of leak $\mathrm{K}^{+}$current by muscarine in granule cells as well as the muscarine-induced enhancement of sEPSCs in Purkinje cells.

\section{Discussion}

Mechanism underlying ACh-induced increase in the

frequency of sEPSCs in Purkinje cells in

the vestibulo-cerebellum

In this study, we showed that the bath application of ACh markedly increased the frequency of sEPSCs in Purkinje cells specifically in the vestibulo-cerebellum. This effect of ACh was mediated exclusively by the activation of muscarinic receptors, 

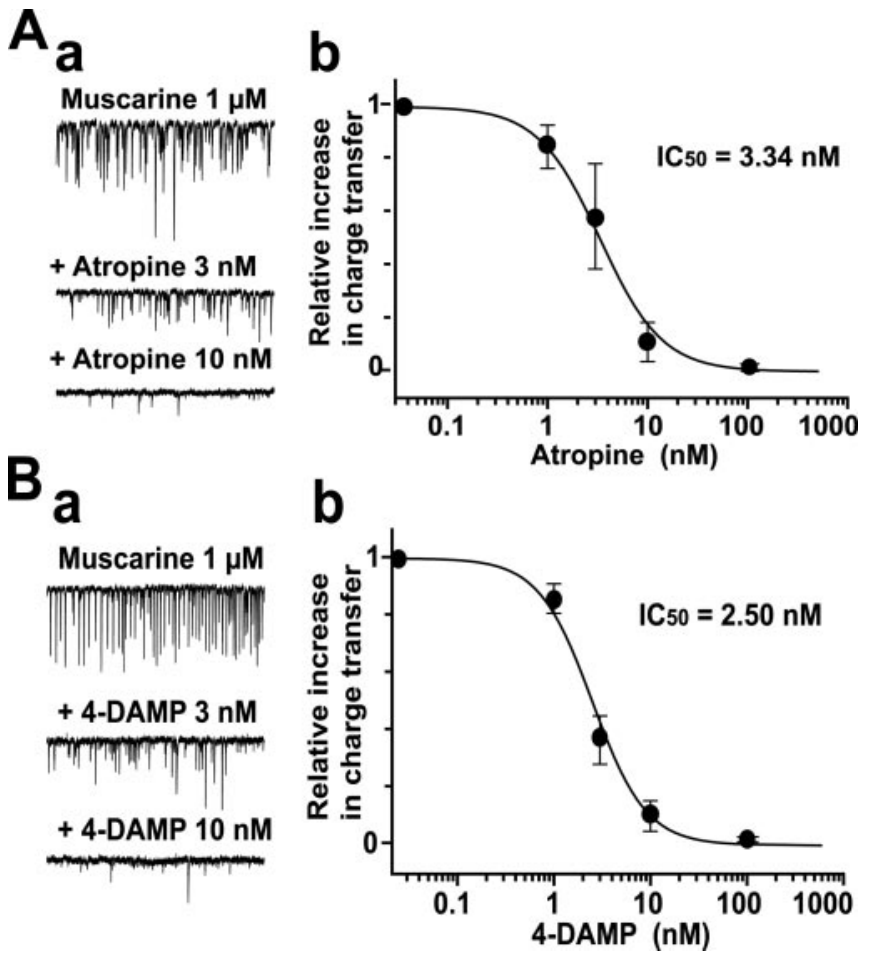

Figure 5. Dose-response relationship of the effect of muscarinic receptor antagonists. $A, a$, Typical traces of $1 \mu \mathrm{m}$ muscarine-induced sEPSCs in the control condition and in the presence of two different concentrations of atropine. $b$, Dose-response relationship of the effect of atropine. The relative peak value of the increase in sEPSC charge transfer induced by $1 \mu \mathrm{m}$ muscarine in the presence of each concentration of atropine, with that induced by $1 \mu \mathrm{m}$ muscarine alone as a reference, is plotted against the concentration of atropine. Plots were fitted to equation $S / S_{\text {cont }}=1 /\left[1+\left(C / C_{50}\right)^{n}\right]$, where $S$ is the peak value of the increase in sEPSC charge transfer in the presence of different concentrations of antagonist; $S_{\text {cont }}$ is that in the absence of antagonist; Cis the concentration of antagonist; and $\mathrm{IC}_{50}$ is the concentration that inhibits the muscarineinduced increase in sEPSC charge transfer by half. The best fit for the effect of atropine yields an $\mathrm{IC}_{50}$ of $3.34 \mathrm{~nm}$ and a Hill coefficient of 1.39. $B, a$, Typical traces of $1 \mu \mathrm{m}$ muscarine-induced sEPSCs in the control condition and in the presence of 4-DAMP ( $M_{3}$ antagonist). $b$, Doseresponse relationship of the effect of 4-DAMP. The best fit yields an $\mathrm{IC}_{50}$ of $2.50 \mathrm{~nm}$ and a Hill coefficient of 1.56. Each circle and bar in $A, b$, and $B, b$, represent the mean $\pm S E M$ of the relative value of the increase in sEPSC charge transfer obtained from $5-13$ cells.

because it was mimicked by muscarine but not by nicotine. The finding that the effect of ACh was abolished by adding TTX to the bathing medium indicated that ACh or muscarine did not act directly on Purkinje cells but increased the excitability of presynaptic excitatory neurons, thereby augmenting the frequency of sEPSCs in Purkinje cells indirectly. It is most likely that these presynaptic neurons are granule cells. In fact, muscarine caused membrane depolarization accompanied by a decrease in membrane conductance by suppressing the leak $\mathrm{K}^{+}$current even in the presence of TTX in a population of granule cells in the vestibulocerebellum. The above notion is compatible with the previous anatomical and pharmacological findings that muscarinic receptors in the cerebellum are concentrated in the granule cells in the vestibulo-cerebellum (Neustadt et al., 1988; Vilaró et al., 1992).

An unexpected finding in this study was that the inhibition by muscarine of the leak $\mathrm{K}^{+}$conductance was detected in only $\sim 15 \%$ of granule cells tested in both current- and voltage-clamp recordings, whereas this drug increased the frequency of sEPSCs in almost all Purkinje cells in the vestibulo-cerebellum. A straightforward interpretation of this result is that only $\sim 15 \%$ of granule cells in the vestibulo-cerebellum are sensitive to muscarine. Alternatively, some unfavorable recording conditions
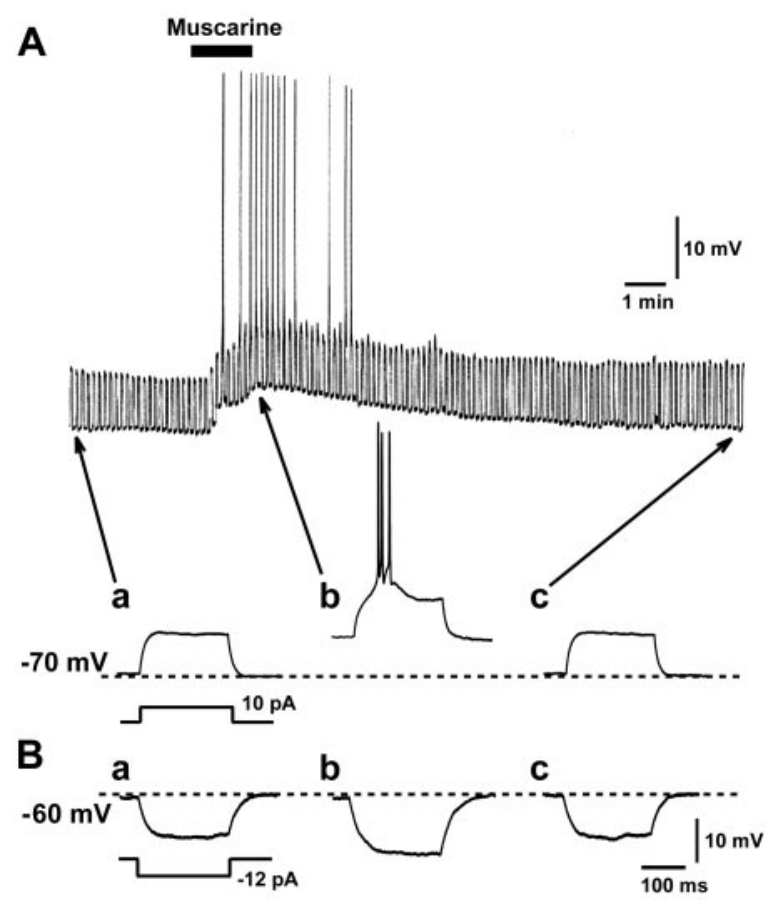

Figure 6. Effects of muscarine on membrane potential and conductance of cerebellar granule cells. $A$, Membrane depolarization induced by $1 \mu$ m muscarine. The membrane conductance was estimated by recording potential change evoked by $10 \mathrm{pA}$ depolarizing current pulses for $250 \mathrm{msec}$ at $0.1 \mathrm{~Hz}$. $a-c$, Voltage changes induced by the depolarizing pulses before, during, and after application of muscarine, respectively. Action potentials were occasionally elicited during muscarine application. Holding potential was maintained at approximately $-70 \mathrm{mV}$ by injecting $D C$ current before muscarine application. $B$, Muscarine-induced decrease in membrane conductance estimated by injecting $12 \mathrm{pA}$ hyperpolarizing current pulses. The $D C$ membrane potential level was maintained at $-60 \mathrm{mV}$ by adjusting the holding current. $a-c$, Voltage traces before, during, and after application of $1 \mu \mathrm{m}$ muscarine, respectively.

would have prevented us from detecting the effect of muscarine in these neurons. To solve this issue, obviously more detailed information is needed regarding the distribution of muscarinic receptors in the granule cell layer in the cerebellum. However, if the above straightforward interpretation is correct, it implies that almost all Purkinje cells in the vestibulo-cerebellum receive the innervation by parallel fibers originating from granule cells with muscarinic receptors at least partly. It is known that a Purkinje cell is innervated by $\sim 200,000$ granule cells (Eccles et al., 1967).

The muscarine-induced increase in the frequency of sEPSCs in Purkinje cells was accompanied by an increase in the mean amplitude of sEPSCs (Fig. $2 B$ ). There was no change in the rise and decay time constants of sEPSCs during this event. Moreover, muscarine did not alter the amplitude of mEPSCs in the presence of TTX. Parallel fiber synapses have a low probability of release (Dittman et al., 2000) and display a prominent paired pulse facilitation of presynaptic origin (Konnerth et al., 1990). Therefore, one possibility would be that short bursts of firing as seen in Figure 6 caused by muscarine augment glutamate release from the presynaptic nerve terminal to each action potential, thereby increasing the mean amplitude of sEPSCs in Purkinje cells. Another possibility would be that the muscarine-sensitive granule cells impinge on Purkinje cells via synapses that have a greater average amplitude than the other granule cells impinging on these neurons and that in the absence of muscarine, the muscarine-sensitive granule cells are mostly silent. Hence the increased activity would come from a different population of synapses than those causing the original currents. In fact, some 


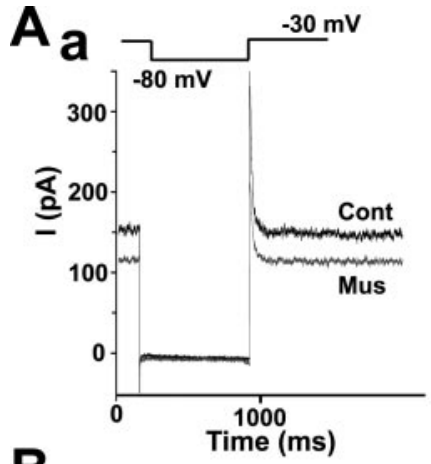

a $2.5 \mathrm{mM} \mathrm{K}^{+}$
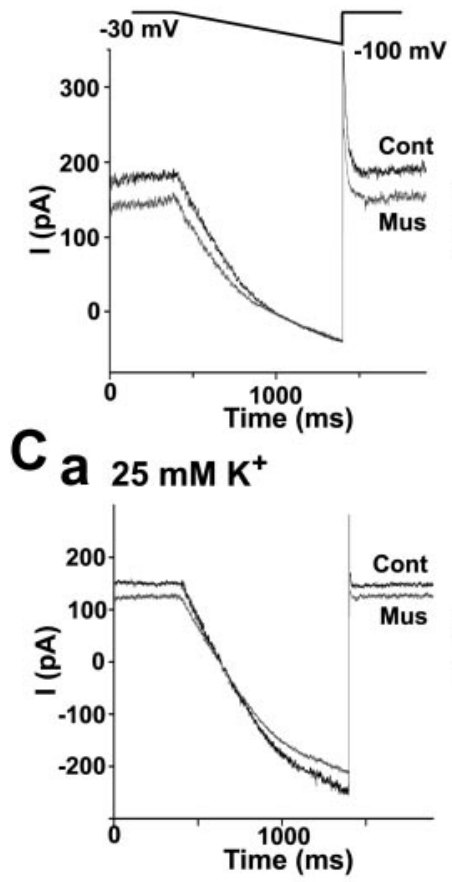
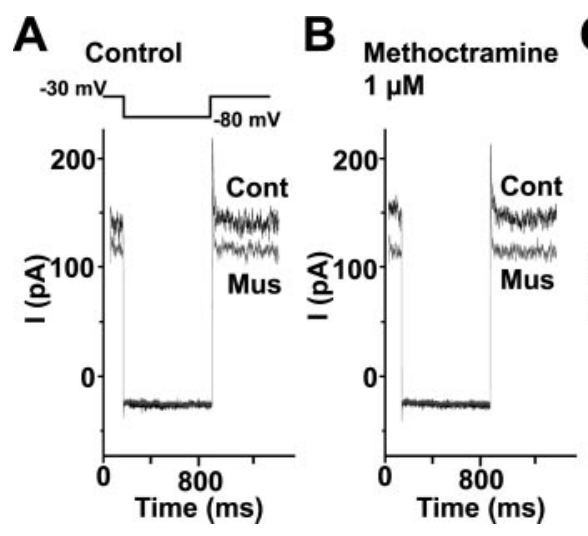

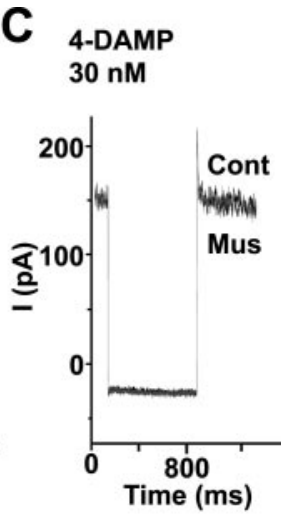

Figure 8. Effects of subtype-selective antagonists of muscarinic receptors on muscarineinduced inhibition of $/ K_{S_{0}}$ in granule cells. $A$, Muscarine-induced inhibition of $/ K_{S_{0}}$ in the control condition. The outward current at $-30 \mathrm{mV}$ was inhibited by $1 \mu \mathrm{m}$ muscarine. $B$, No effect of 1 $\mu \mathrm{m}$ methoctramine ( $\mathrm{M}_{2}$ antagonist) on muscarine-sensitive current. $C$, Abolition of muscarinesensitive current by $30 \mathrm{~nm}$ 4-DAMP ( $\mathrm{M}_{3}$ antagonist). Cont, Control; Mus, muscarine.

cortex (Madison et al., 1987; Benson et al., 1988; Jones and Baughman, 1992). In the cerebellum, a muscarine-induced decrease in voltage-independent leak $\mathrm{K}^{+}$current has been reported in cultured granule cells (Watkins and Mathie, 1996). It is a noninactivating current that shows a quasi-instantaneous decrease in amplitude on membrane hyperpolarization. This $\mathrm{K}^{+}$current is attributable to the expression of two-pore-domain acid-sensitive $\mathrm{K}^{+}$channel-1 (TASK-1) (Millar et al., 2000), a member of the growing family of two-pore-forming $\mathrm{K}^{+}$(2-PK) channels with four transmembrane domains (Lesage et al., 1996).

With respect to the cholinergic inputs to cerebellar granule cells, the vestibulo-cerebellum including the uvula and nodulus contains dense cholinergic mossy fiber projections originating from neurons in the vestibular nucleus (Ojima et al., 1989; Barmack et al., 1992). In this study, we showed in the current-clamp recording that muscarine elicited membrane depolarization accompanied by a decrease in the membrane conductance in a population of granule cells in the vestibulo-cerebellum. In the voltage-clamp condition, we also detected the leak $\mathrm{K}^{+}$current that had the characteristic features of $I \mathrm{~K}_{\mathrm{SO}}$ in these neurons. This $\mathrm{K}^{+}$current was highly sensitive to muscarine, and its selective $\mathrm{K}^{+}$ permeability was confirmed by varying the external $\mathrm{K}^{+}$concentration and estimating the reversal potential. We therefore conclude that a population of granule cells possesses muscarinesensitive $\mathrm{K}^{+}$channels with the known properties of 2-PK channels, such as TASK-1 (Duprat et al., 1997; Millar et al., 2000; Talley et al., 2000). Cholinergic inputs from the vestibular nucleus would have a profound influence on the excitability of Purkinje cells in the vestibulo-cerebellum via these muscarinesensitive $\mathrm{K}^{+}$channels in granule cells.

\section{Inhibition of effects of muscarine by $\mathrm{M}_{3}$ antagonist}

Molecular cloning studies have revealed the existence of five distinct subtypes of muscarinic receptors (m1-m5), which are widely expressed in the CNS (Bonner et al., 1987; Levey et al., 1991). An immunoprecipitation study has shown that in the rat cerebellum, $\mathrm{m} 2$ receptors are predominant, and $\mathrm{m} 3$ receptors are present in a lesser amount, whereas $\mathrm{m} 1, \mathrm{~m} 4$, and $\mathrm{m} 5$ receptors are virtually absent (Tice et al., 1996). In addition, Northern blot analysis has also shown that $\mathrm{m} 2$ and $\mathrm{m} 3$ but not $\mathrm{m} 1$ and $\mathrm{m} 4$ muscarinic receptor mRNAs are expressed in cerebellar granule cells (Fukamauchi et al., 1991). Several other studies are generally 
consistent with these results (Alonso et al., 1990; Waelbroeck et al., 1990; Vilaró et al., 1992; Jaarsma et al., 1997). On the other hand, muscarinic receptors are pharmacologically divided into three subtypes, $M_{1}-M_{3}$ (Hulme et al., 1990). It has been shown that the antagonist-binding properties of both $\mathrm{m} 1$ and $\mathrm{m} 4$ receptors were similar to those of $M_{1}$ receptors, and those of $\mathrm{m} 2$ and $\mathrm{m} 3$ receptors correlated well with those of $\mathrm{M}_{2}$ and $\mathrm{M}_{3}$ subtypes, respectively (Dörje et al., 1991).

In this study, we attempted to determine which of the $\mathrm{M}_{2}$ or $\mathrm{M}_{3}$ receptors underlies the effects of muscarine on the occurrence of sEPSCs in Purkinje cells using the five antagonists of muscarinic receptors. Atropine, a subtype-nonselective antagonist, has $K_{\mathrm{i}}$ values of 0.5-1.2 nM for $\mathrm{M}_{2}$ receptors and 0.2-1.2 $\mathrm{nM}$ for $\mathrm{M}_{3}$ receptors (Hulme et al., 1990; Caulfield and Birdsall, 1998). Methoctramine and himbacine, antagonists relatively selective to the $\mathrm{M}_{2}$ subtype, have $K_{\mathrm{i}}$ values of 5-20 and 5-10 nM for $\mathrm{M}_{2}$ receptors and 126-794 and 40-126 nM for $\mathrm{M}_{3}$ receptors, respectively (Caulfield and Birdsall, 1998; Loury et al., 1999). 4-DAMP and $p$-F-HHSiD, antagonists relatively selective to the $\mathrm{M}_{3}$ subtype, have $K_{\mathrm{i}}$ values of 4-16 and 131-676 nM for $\mathrm{M}_{2}$ receptors and 0.5-1.6 and 15-40 nм for $\mathrm{M}_{3}$ receptors, respectively (Dörje et al., 1991; Dong et al., 1995; Caulfield and Birdsall, 1998). On the basis of the above information, we thought as follows: If $\mathrm{M}_{2}$ receptors are responsible for the muscarine effect on sEPSCs, it would be expected from the $K_{\mathrm{i}}$ values for $\mathrm{M}_{2}$ receptors that the $\mathrm{IC}_{50}$ values of methoctramine and himbacine would be $\sim 15$ - and $\sim 10$-fold higher than that of atropine, respectively. Furthermore, the $\mathrm{IC}_{50}$ values of 4 -DAMP and $p$-F-HHSiD would be $\sim 10$ - and $\sim 480$-fold higher than that of atropine. On the other hand, if $\mathrm{M}_{3}$ receptors are responsible, the $\mathrm{IC}_{50}$ values of 4 -DAMP and $p$-FHHSiD would be expected to be similar to and $\sim 40$-fold higher than that of atropine, respectively. Furthermore, the $\mathrm{IC}_{50}$ values of methoctramine and himbacine would be $\sim 650$ - and $\sim 120$ fold higher than that of atropine. The actual $\mathrm{IC}_{50}$ values of these antagonists estimated in this study (Fig. 5) were $\sim 840$-fold higher (methoctramine), 130 -fold higher (himbacine), almost similar to (4-DAMP) and $\sim 20$-fold higher ( $p$-F-HHSiD) than that of atropine. Taken together, these results strongly suggest that the muscarine-induced increase in sEPSC charge transfer in Purkinje cells was attributable predominantly to the activation of $\mathrm{M}_{3}$ receptors. In addition, the inhibition by muscarine of the leak $\mathrm{K}^{+}$current in granule cells was completely abolished by $30 \mathrm{nM}$ 4 -DAMP but was unaffected by $1 \mu \mathrm{M}$ methoctramine, again suggesting that the effect of muscarine was mediated by the activation of $\mathrm{M}_{3}$ receptors in the vestibulo-cerebellum. This provides additional support to the notion that $\mathrm{ACh}$ increases the firing frequency of granule cells by inhibiting the leak $\mathrm{K}^{+}$current, which in turn increases the frequency of sEPSCs in Purkinje cells in the vestibulo-cerebellum.

It has been reported that $\mathrm{m}_{5}$ receptors are expressed in the cerebellum (Wei et al., 1994), and that they have antagonist selectivity similar to that of $\mathrm{m}_{3}$ receptors (Caulfield and Birdsall, 1998). To date, however, the expression of $\mathrm{m}_{5}$ receptors in the cerebellum is controversial (Levey et al., 1991; Tice et al., 1996). Further study is needed to estimate the contribution of $\mathrm{m}_{5}$ receptors to the muscarine-induced facilitation in the vestibulo-cerebellum.

\section{References}

Alonso R, Didier M, Soubrie P (1990) $\left[{ }^{3} \mathrm{H}\right] N$-methylscopolamine binding studies reveal M2 and M3 muscarinic receptor subtypes on cerebellar granule cells in primary culture. J Neurochem 55:334-337.

Altman J, Bayer SA (1997) Development of the cerebellar system: in relation to its evolution, structure, and functions. New York: CRC.

Andre P, Pompeiano O, White SR (1993) Activation of muscarinic recep- tors induces a long-lasting enhancement of Purkinje cell responses to glutamate. Brain Res 617:28-36.

Araujo DM, Lapchak PA, Quirion R (1991) Heterogeneous binding of $\left[{ }^{3} \mathrm{H}\right] 4$-DAMP to muscarinic cholinergic sites in the rat brain: evidence from membrane binding and autoradiographic studies. Synapse 9:165-176.

Barmack NH, Baughman RW, Eckenstein FP, Shojaku H (1992) Secondary vestibular cholinergic projection to the cerebellum of rabbit and rat as revealed by choline acetyltransferase immunohistochemistry, retrograde and orthograde tracers. J Comp Neurol 317:250-270.

Benson DM, Blitzer RD, Landau EM (1988) An analysis of the depolarization produced in guinea-pig hippocampus by cholinergic receptor stimulation. J Physiol (Lond) 404:479-496.

Bonner TI, Buckley NJ, Young AC, Brann MR (1987) Identification of a family of muscarinic acetylcholine receptor genes. Science 237:527-532.

Brickley SG, Revilla V, Cull-Candy SG, Wisden W, Farrant M (2001) Adaptive regulation of neuronal excitability by a voltage-independent potassium conductance. Nature 409:88-92.

Caulfield MP, Birdsall NJ (1998) International Union of Pharmacology. XVII. Classification of muscarinic acetylcholine receptors. Pharmacol Rev 50:279-290.

Crawford JM, Curtis DR, Voorhoeve PE, Wilson VJ (1966) Acetylcholine sensitivity of cerebellar neurones in the cat. J Physiol (Lond) 186:139-165.

Crepel F, Dhanjal SS (1982) Cholinergic mechanisms and neurotransmission in the cerebellum of the rat: an in vitro study. Brain Res 244:59-68.

Dittman JS, Kreitzer AC, Regehr WG (2000) Interplay between facilitation, depression, and residual calcium at three presynaptic terminals. J Neurosci 20:1374-1385.

Dong GZ, Kameyama K, Rinken A, Haga T (1995) Ligand binding properties of muscarinic acetylcholine receptor subtypes (m1-m5) expressed in baculovirus-infected insect cells. J Pharmacol Exp Ther 274:378-384.

Dörje F, Wess J, Lambrecht G, Tacke R, Mutschler E, Brann MR (1991) Antagonist binding profiles of five cloned human muscarinic receptor subtypes. J Pharmacol Exp Ther 256:727-733.

Duprat F, Lesage F, Fink M, Reyes R, Heurteaux C, Lazdunski M (1997) TASK, a human background $\mathrm{K}^{+}$channel to sense external $\mathrm{pH}$ variations near physiological pH. EMBO J 16:5464-5471.

Eccles JC, Ito M, Szentágothai J (1967) The cerebellum as a neuronal machine. New York: Springer.

Edwards FA, Konnerth A, Sakmann B, Takahashi T (1989) A thin slice preparation for patch clamp recordings from neurones of the mammalian central nervous system. Pflügers Arch 414:600-612.

Fukamauchi F, Hough C, Chuang DM (1991) Expression and agonistinduced down-regulation of mRNAs of m2- and m3-muscarinic acetylcholine receptors in cultured cerebellar granule cells. J Neurochem 56:716-719.

Fukamauchi F, Saunders PA, Hough C, Chuang DM (1993) Agonistinduced down-regulation and antagonist-induced up-regulation of $\mathrm{m} 2$ and $\mathrm{m} 3$-muscarinic acetylcholine receptor mRNA and protein in cultured cerebellar granule cells. Mol Pharmacol 44:940-949.

Hulme EC, Birdsall NJ, Buckley NJ (1990) Muscarinic receptor subtypes. Annu Rev Pharmacol Toxicol 30:633-673.

Iino M, Goto K, Kakegawa W, Okado H, Sudo M, Ishiuchi S, Miwa A, Takayasu Y, Saito I, Tsuzuki K, Ozawa S (2001) Glia-synapse interaction through $\mathrm{Ca}^{2+}$-permeable AMPA receptors in Bergmann glia. Science 292:926-929.

Jaarsma D, Ruigrok TJ, Caffé R, Cozzari C, Levey AI, Mugnaini E, Voogd J (1997) Cholinergic innervation and receptors in the cerebellum. Prog Brain Res 114:67-96.

Jones KA, Baughman RW (1992) Muscarinic M3 receptors inhibit a leak conductance in rat corticocallosal neurons. NeuroReport 3:889-892.

Konnerth A, Llano I, Armstrong CM (1990) Synaptic currents in cerebellar Purkinje cells. Proc Natl Acad Sci USA 87:2662-2665.

Lesage F, Guillemare E, Fink M, Duprat F, Lazdunski M, Romey G, Barhanin J (1996) TWIK-1, a ubiquitous human weakly inward rectifying K+ channel with a novel structure. EMBO J 15:1004-1011.

Levey AI, Kitt CA, Simonds WF, Price DL, Brann MR (1991) Identification and localization of muscarinic acetylcholine receptor proteins in brain with subtype-specific antibodies. J Neurosci 11:3218-3226.

Loury DN, Hegde SS, Bonhaus DW, Eglen RM (1999) Ionic strength of assay buffers influences antagonist binding affinity estimates at muscarinic M1-M5 cholinoceptors. Life Sci 64:557. 
Madison DV, Lancaster B, Nicoll RA (1987) Voltage-clamp analysis of cholinergic action in the hippocampus. J Neurosci 7:733-741.

McCance I, Phillis JW (1964) Discharge patterns of elements in cat cerebellar cortex, and their responses to ionophoretically applied drugs. Nature 204:844-846.

McCance I, Phillis JW (1968) Cholinergic mechanisms in the cerebellar cortex. Int J Neuropharmacol 7:447-462.

Millar JA, Barratt L, Southan AP, Page KM, Fyffe RE, Robertson B, Mathie A (2000) A functional role for the two-pore domain potassium channel TASK-1 in cerebellar granule neurons. Proc Natl Acad Sci USA 97:3614-3618.

Neustadt A, Frostholm A, Rotter A (1988) Topographical distribution of muscarinic cholinergic receptors in the cerebellar cortex of the mouse, rat, guinea pig, and rabbit: a species comparison. J Comp Neurol 272:317-330.

Ojima H, Kawajiri S, Yamasaki T (1989) Cholinergic innervation of the rat cerebellum: qualitative and quantitative analyses of elements immunoreactive to a monoclonal antibody against choline acetyltransferase. J Comp Neurol 290:41-52.

Rae J, Cooper K, Gates P, Watsky M (1991) Low access resistance perforated patch recordings using amphotericin B. J Neurosci Methods 37:15-26.

Schäfer MK, Eiden LE, Weihe E (1998) Cholinergic neurons and terminal fields revealed by immunohistochemistry for the vesicular acetylcholine transporter. I. Central nervous system. Neuroscience 84:331-359.

Spencer Jr DG, Horváth E, Traber J (1986) Direct autoradiographic determination of M1 and M2 muscarinic acetylcholine receptor distribution in the rat brain: relation to cholinergic nuclei and projections. Brain Res 380:59-68.

Storm JF (1990) Potassium currents in hippocampal pyramidal cells. Prog Brain Res 83:161-187.

Swanson LW, Simmons DM, Whiting PJ, Lindstrom J (1987) Immunohis- tochemical localization of neuronal nicotinic receptors in the rodent central nervous system. J Neurosci 7:3334-3342.

Talley EM, Lei Q, Sirois JE, Bayliss DA (2000) TASK-1, a two-pore domain $\mathrm{K}^{+}$channel, is modulated by multiple neurotransmitters in motoneurons. Neuron 25:399-410.

Tan HS, Collewijn H (1991) Cholinergic modulation of optokinetic and vestibulo-ocular responses: a study with microinjections in the flocculus of the rabbit. Exp Brain Res 85:475-481.

Tan HS, Collewijn H, Van der SJ (1993) Unilateral cholinergic stimulation of the rabbit's cerebellar flocculus: asymmetric effects on optokinetic responses. Exp Brain Res 92:375-384.

Tice MA, Hashemi T, Taylor LA, McQuade RD (1996) Distribution of muscarinic receptor subtypes in rat brain from postnatal to old age. Dev Brain Res 92:70-76.

Vilaró MT, Wiederhold KH, Palacios JM, Mengod G (1992) Muscarinic M2 receptor mRNA expression and receptor binding in cholinergic and noncholinergic cells in the rat brain: a correlative study using in situ hybridization histochemistry and receptor autoradiography. Neuroscience 47:367-393.

Wada E, Wada K, Boulter J, Deneris E, Heinemann S, Patrick J, Swanson LW (1989) Distribution of alpha 2, alpha 3, alpha 4, and beta 2 neuronal nicotinic receptor subunit mRNAs in the central nervous system: a hybridization histochemical study in the rat. J Comp Neurol 284:314-335.

Waelbroeck M, Tastenoy M, Camus J, Christophe J (1990) Binding of selective antagonists to four muscarinic receptors (M1 to M4) in rat forebrain. Mol Pharmacol 38:267-273.

Watkins CS, Mathie A (1996) A non-inactivating $\mathrm{K}^{+}$current sensitive to muscarinic receptor activation in rat cultured cerebellar granule neurons. J Physiol (Lond) 491:401-412.

Wei J, Walton EA, Milici A, Buccafusco JJ (1994) m1-m5 muscarinic receptor distribution in rat CNS by RT-PCR and HPLC. J Neurochem 63: qj815-821. 